\title{
Persepsi Petani terhadap Hutan Rakyat Pola Agroforestri di Kabupaten Wonogiri, Provinsi Jawa Tengah
}

\author{
Farmer's Perception of Agroforestry Community Forest \\ in Wonogiri Regency, Central Java Province
}

\author{
Indiyah Hudiyani ${ }^{1}$, Ninuk Purnaningsih ${ }^{2}$, Pang S. Asngari ${ }^{2}$, Hardjanto ${ }^{3}$ \\ ${ }^{1}$ Pusat Standardisasi Lingkungan dan Kehutanan, Kementerian Lingkungan Hidup dan Kehutanan RI, Jakarta \\ ${ }^{2}$ Departemen Sains Komunikasi dan Pengembangan Masyarakat, Fakultas Ekologi Manusia, \\ Institut Pertanian Bogor, Bogor \\ ${ }^{3}$ Departemen Manajemen Hutan, Fakultas Kehutanan, Institut Pertanian Bogor, Bogor
}

\begin{abstract}
The success of community forest (CF) development in Wonogiri is really dependent on farmers' perceptions. Their perception on the environment issues is an important factor; therefore, it should be explored. The objectives of the study were to assess farmers 'perceptions of CF with agroforestry patterns and to find out farmer's characteristics which are related to the perception of farmers on the agroforestry patterns of CF in Wonogiri. The research was conducted from December 2015 to April 2016. The research population accounts for 2.431 farmers of agroforestry community forest in Wonogiri Regencyt, and the data were collected from 246 farmers who adopt the agroforestry patterns of CF. The study used a simple random sampling technique. The research data are of primary and secondary types. Further, the data were analyzed descriptively and qualitatively, and a Rank Spearmen Correlation Test was used to test the hypotheses already formulated. The research results showed that (1) the perception of farmers was of high level, (2) the perception was closely related to formal education, non formal education, and family's size.
\end{abstract}

Keywords: perception, community forests, agroforestry patterns, farmer's characteristics

\begin{abstract}
Abstrak
Keberhasilan pembangunan hutan rakyat pola agroforestri di Kabupaten Wonogiri tidak terlepas dari persepsi petani mengenai hutan rakyat pola agroforestri. Persepsi individu terhadap lingkungannya merupakan faktor penting dan sangat menentukan tindakan yang dilakukannya. Tujuan penelitian ini adalah untuk mengkaji persepsi petani mengenai hutan rakyat pola agroforestri dan menemukan karakteristik petani yang berhubungan dengan persepsi petani tentang hutan rakyat pola agroforestri di Kabupaten Wonogiri. Penelitian dilakukan pada Desember 2015 hingga April 2016 di Kabupaten Wonogiri. Populasi penelitian adalah kepala keluarga/ rumah tangga petani hutan rakyat dengan jumlah 2.431 orang dan pengumpulan data dilakukan kepada 246 petani hutan rakyat. Teknik penentuan sampel dilakukan secara simple random sampling. Data penelitian meliputi data primer dan data sekunder. Selanjutnya data dianalisis secara deskriptif kualitatif dan untuk menguji hipotesis yang telah dirumuskan digunakan Uji Korelasi Rank Spearman. Hasil penelitian menunjukkan bahwa petani memiliki persepsi yang tinggi terhadap pengelolaan hutan rakyat pola agroforestri (3,14 Skala Likert) dan manfaat hutan rakyat pola agroforestri (3,09 Skala Likert). Karakteristik petani yang berkorelasi dengan persepsi petani adalah pendidikan formal, pendidikan non formal, dan jumlah tanggungan keluarga.
\end{abstract}

Kata kunci: persepsi petani, hutan rakyat, pola agroforestri, karakteristik petani hutan

\section{Pendahuluan}

Undang-Undang nomor 41 tahun 1999 tentang Kehutanan menyebutkan "hutan adalah suatu kesatuan ekosistem berupa hamparan lahan berisi sumberdaya alam hayati yang didominasi pepohonan dalam persekutuan alam lingkungannya, yang satu dengan lainnya tidak dapat dipisahkan." Hutan berdasarkan statusnya dibagi menjadi hutan negara dan hutan hak. Hutan negara adalah hutan yang berada pada tanah negara, sedangkan hutan hak adalah hutan yang berada di tanah/lahan milik.

Undang-Undang ini menyebutkan bahwa hutan rakyat merupakan hutan hak, tetapi banyak ahli yang berpendapat bahwa hutan rakyat adalah hutan yang dikelola oleh masyarakat, baik yang berada di lahan negara maupun lahan milik. Berbagai bentuk pengelolaan hutan oleh masyarakat banyak dijumpai di berbagai daerah di tanah air, antara lain Rempong Damar di Krui (Lampung Barat), Hutan Adat Suku

${ }^{1}$ Korespondensi penulis E-mail: iin_indie@yahoo.co.id 
Talang Mamak di Riau, Hutan Adat Dayak Benuak di Kalimantan Timur, Hutan Rakyat di Tana Toraja (Simon, 2010).

Pengelolaan hutan yang dilakukan oleh masyarakat menunjukkan kondisi yang lebih baik dibandingkan pengelolaan yang dilakukan oleh swasta. Hutan yang selama ini dikelola oleh swasta menunjukkan kondisi yang sangat memprihatinkan. Berbagai permasalahan lingkungan muncul akibat pengelolaan hutan yang kurang bijak. Hutan hanya dipandang sebagai penghasil kayu semata tanpa memperhatikan aspek lainnya. Akibatnya, hutan mengalami degradasi dan deforestasi. Data Kemenhut (2010) menunjukkan laju deforestasi antara tahun 2000- 2005 mencapai 1,08 juta hektar/tahun. Hutan dan lahan kritis di Indonesia mencapai 77,8 juta hektar yang terdiri dari lahan sangat kritis 6,9 juta hektar, lahan kritis 23,3 juta hektar, dan agak kritis 47,6 juta hektar.

Kondisi sebaliknya, hutan yang dikelola masyarakat masih mampu menjalankan fungsinya (fungsi ekonomi, ekologi, dan sosial) dengan baik hingga saat ini (Simon, 2010). Hutan menjadi salah satu penopang hidup masyarakat, menjaga keseimbangan ekosistem, dan menjadi salah satu wahana yang digunakan oleh masyarakat untuk berinteraksi satu sama lain. Masyarakat dan hutan memiliki hubungan yang sangat erat, hutan menjadi bagian penting dalam kehidupan masyarakat. Kearifan lokal yang digunakan masyarakat untuk mengelola hutan mampu membuktikan bahwa pengelolaan hutan yang dilakukan masyarakat mampu menjaga berjalannya fungsi hutan dengan baik.

Kabupaten Wonogiri merupakan salah satu kabupaten di Provinsi Jawa Tengah yang telah berhasil mengembangkan hutan rakyat pola agroforestri. Agroforestri menurut King (Kartasubrata, 2003) adalah suatu sistem pengelolaan lahan dengan berasaskan kelestarian yang meningkatkan hasil lahan secara keseluruhan dengan mengombinasikan tanaman semusim, tanaman hutan dan atau ternak secara bersamaan atau berurutan pada unit lahan yang sama dan menerapkan cara-cara pengelolaan yang sesuai dengan kebudayaan penduduk setempat. Jenis tanaman kayu yang ditanam oleh petani didominasi oleh jati dan mahoni. Wonogiri yang sekarang sangat jauh berbeda dengan Wonogiri tempo dulu (sebelum Tahun 1960-an). Kondisi Wonogiri dahulu sangat memprihatinkan dengan kondisi lahan yang miskin hara sehingga wilayah ini sebagian besar terdiri dari batuan kapur yang besar dan terjal. Saat ini Wonogiri tampak hijau oleh adanya pepohonan terutama didominasi jenis jati. Jati merupakan salah satu jenis tanaman yang mampu hidup dalam kondisi tanah berkapur dan miskin hara. Untuk memanfaatkan lahan di bawah tegakan pohon, petani menanam tanaman rimpang (kunyit, temu lawak).

Kondisi hutan rakyat di Wonogiri serupa dengan kondisi hutan rakyat di Kabupaten Purworejo (Suryaningsih et al., 2012), petani menanam tanaman kayu, tanaman multiguna atau Multiple Purposes Trees Species (MPTS), dan tanaman bawah tegakan. Tanaman kayu yang ditanam adalah mahoni, jati, akasia, albizia, dan sonokeling. Tanaman MPTS yang ditanam yaitu bambu, pete, durian, cengkeh, rambutan, pisang, dan melinjo. Tanaman yang ditanam di bawah tegakan adalah empon-empon yaitu temulawak, lengkuas, kapulaga, kunyit, sereh, dan tanaman pangan (umbi-umbian) seperti singkong, talas, suweg.

Sistem agroforestri memungkinkan masyarakat dapat memenuhi kebutuhan harian, jangka menengah, dan jangka panjang (Awang et al., 2007). Kebutuhan jangka pendek dapat dipenuhi dari tanaman cabai, kebutuhan jangka menengah dapat dipenuhi dari tanaman buah dan tanaman palawija, kebutuhan jangka panjang dapat dipenuhi dari tanaman kayu. Penelitian Hlaing \& Inoue (2013) di Myanmar menunjukkan bahwa manfaat ekonomi yang diperoleh petani dari hutan rakyat pola agroforestri meskipun tidak banyak namun dapat meningkatkan penghasilan petani. Penghasilan ini dapat digunakan untuk memenuhi kebutuhan keluarga yang memiliki tanggungan jiwa sebesar 4-5 orang. Selain itu, petani terutama para ibu dapat mengurangi pengeluaran rumah tangganya karena beberapa bahan makanan dapat diperoleh dari hutannya. Pengeluaran lain yang dapat dikurangi petani adalah pengeluaran untuk pembelian bahan bakar karena petani memanfaatkan ranting kayu rakyat sebagai kayu bakar dan digunakan untuk keperluan memasak makanan. Selain itu, ibu rumah tangga juga memiliki waktu luang untuk melakukan kegiatankegiatan di luar pertanian. Hal ini dimungkinkan karena hutan rakyat pola agroforestri dapat menyediakan pakan ternak sehingga dapat menghemat waktu. Jadi, meskipun pendapatan yang diperoleh dari hutan rakyat relatif kecil, namun hutan rakyat dapat membantu petani mengurangi pengeluaran rumah tangganya.

Keberhasilan hutan rakyat diduga tidak terlepas 
dari persepsi petani mengenai hutan rakyat. Asngari (1984) berdasarkan beberapa pakar menyatakan bahwa persepsi adalah interpretasi individu akan makna sesuatu baginya dalam kaitan dengan "dunia"nya. Orang bertindak sebagian dilandasi oleh persepsi mereka pada suatu situasi sehingga persepsi individu terhadap lingkungannya merupakan faktor penting dan sangat menentukan tindakan yang dilakukannya.

Penelitian Rohadi (2012) menunjukan adanya perbedaan persepsi mengenai hutan rakyat, antara petani hutan di Kabupaten Gunung Kidul dan petani di Kabupaten Tanah laut. Petani hutan di Gunung Kidul memandang hutan merupakan bagian dari budayanya. Tanaman jatu memegang peranan penting dalam usahatani. Tanaman jati dipandang sebagai tabungan keluarga dan sumber uang tunai pada saat darurat, sedangkan petani di Kabupaten Tanah Laut Kalimantan Selatan memandang hutan rakyat sebagai usaha dalam rangka meragamkan sumber pendapatan. Hal ini berdampak pada pengelolaan hutan yang dilakukan. Petani Gunung Kidul mengusahakan hutan rakyat secara terintegrasi dengan tanaman pangan di lahan-lahan produktif, sedangkan petani di Tanah Laut mengusahakan hutannya berdasarkan dinamika pasar baik jenis maupun volumenya. Sistem pemanenan yang dilakukan petani Gunung Kidup adalah sistem tebang butuh, ketika membutuhkan dana maka mereka akan memanen kayunya. Berbeda dengan petani di Tanah Laut yang memanen kayunya dengan sistem tebang habis.

Suryaningsih et al., (2012) menyatakan bahwa persepsi masyarakat di Desa Karangrejo Kabupaten Purworejo terhadap hutan rakyat sangat baik. Masyarakat memandang hutan rakyat mampu menjalankan fungsi ekonomi, sosial, dan okologi dengan baik. Fungsi ekonomi ditunjukkan dengan adanya peningkatan pendapatan, fungsi ekologi ditunjukkan dengan kemampuan hutan rakyat dalam mencegah banjir dan tanah longsor, memunculkan sumber air, serta konservasi tanah. Fungsi sosial hutan rakyat ditunjukkan dengan adanya lapangan pekerjaan, ekowisata, dan peluang kerjasama.

Mengingat pentingnya persepsi petani mengenai hutan rakyat maka rumusan masalah penelitian ini adalah bagaimana persepsi petani mengenai hutan rakyat dan karakteristik petani apakah yang berhubungan dengan persepsi petani mengenai hutan rakyat pola agroforestri. Berdasarkan permasalahan penelitian tersebut maka tujuan penelitian adalah untuk mengkaji persepsi petani mengenai hutan rakyat pola agroforestri dan menemukan karakteristik petani hutan yang berhubungan dengan persepsi petani tentang hutan rakyat pola agroforestri di Kabupaten Wonogiri. Karakteristik petani hutan yang diduga memiliki hubungan dengan persepsi petani tentang hutan rakyat adalah pendidikan formal, pendidikan non formal, pendapatan, tanggungan keluarga, dan pengalaman.

\section{Metode Penelitian}

Lokasi penelitian adalah di Kabupaten Wonogiri, yaitu Kecamatan Giriwoyo (Desa Sejati, Desa Guwotirto, Desa Tirtosuworo, dan Kelurahan Girikikis) dan Kecamatan Batuwarno (Kelurahan Selopuro). Pemilihan lokasi dilakukan secara sengaja (purposive), yaitu desa/kelurahan yang telah memperoleh pengakuan (sertifikat) ekolabel, yaitu pengakuan bahwa hutan rakyat tersebut telah dikelola secara ramah lingkungan.

Populasi penelitian adalah kepala keluarga/ rumah tangga petani hutan rakyat dengan jumlah 2.431 orang. Besarnya sampel ditetapkan dengan berdasarkan jumlah populasinya (Neuman, 2000). Penentuan jumlah sampel untuk populasi yang berukuran sedang (sekitar 1.000 - 10.000), diperlukan perbandingan sampel yaitu sekitar $10 \%$. Berdasarkan jumlah populasinya maka sampel dalam penelitian ini berjumlah 246 orang. Responden merupakan kepala rumah tangga petani hutan rakyat. Pemilihan desa dilakukan secara sengaja (purpossive), yaitu desa yang sudah dinyatakan mampu mengelola hutannya secara lestari yang dibuktikan dengan diperolehnya sertifikat "Pengelolaan Hutan Bersama Masyarakat Lestari (PHBML)", sedangkan penentuan sampel penelitian dilakukan secara acak (simple random sampling) di tingkat desa.

Pengumpulan data primer dilakukan dengan cara pengisian kuesioner, wawancara, dan observasi langsung. Data sekunder diperoleh dari berbagai kantor/ instansi terkait. Kuisioner terdiri dari 22 pernyataan berkenaan dengan pengelolaan dan manfaat hutan rakyat pola agroforestri di Wonogiri. Pernyataan 1 sampai dengan 17 berkaitan dengan pengelolaan hutan rakyat, sedangkan pernyataan 18 sampai dengan 22 berkaitan dengan manfaat hutan rakyat pola agroforestri.

Pengukuran persepsi dilakukan dengan menggunakan Skala Likert. Skala Likert terdiri dari sejumlah pernyataan, baik pernyataan positif maupun 
pernyataan negatif. Bentuk pernyataan positif adalah bentuk pernyataan yang menjadi indikasi sikap positif, dan bentuk pernyataan negatif adalah bentuk yaang menjadi indikasi sikap negatif. Untuk penelitian ini, Skala Likert yang digunakan telah dimodifikasi dengan menghilangkan jawaban "ragu-ragu atau netral" sehingga hanya tersedia 4 pilihan jawaban, yaitu 'Sangat Setuju, Setuju, Tidak Setuju, dan Sangat Tidak Setuju." Tujuannya adalah untuk menghindari terjadinya bias karena kecenderungan responden akan memilih jawaban "netral" sehingga dapat menjadi sumber bias. Pemberian skor untuk Skala Likert adalah untuk pernyataan positif diberi Skor 4 untuk jawaban Sangat Setuju, Skor 3 untuk jawaban Setuju, Skor 2 untuk jawaban Tidak Setuju, dan Skor 1 untuk jawaban Sangat Tidak Setuju.

Analisis data dilakukan secara statistik deskriptif dan analisis inferensial. Analisis deskriptif yaitu dengan menampilkan distribusi frekuensi, persentase, dan rataan, serta analisis inferensial dengan menggunakan uji Rank Spearman. Analisis statistik deskriptif untuk menggambarkan karakteristik petani dan persepsi petani mengenai hutan rakyat pola agroforestri. Uji Rank Spearman digunakan untuk mengetahui korelasi antara karakteristik petani dengan persepsi petani mengenai hutan rakyat pola agroforestri.

\section{Hasil dan Pembahasan}

\section{Gambaran Umum Lokasi Penelitian}

Lokasi penelitian adalah Kecamatan Batuwarno dan Kecamatan Giriwoyo. Tepatnya adalah Kelurahan Selopuro (Kecamatan Batuwarno), dan Desa Sejati, Desa Tirtosuworo, Desa Guwotirto, dan Kelurahan Girikikis (Kecamatan Giriwoyo). Kelima desa/kelurahan ini merupakan desa/kelurahan yang telah dinyatakan berhasil dalam membangun dan mengembangkan hutan rakyat. Keberhasilannya dalam mengembangkan hutan rakyat dituangkan dalam bentuk sertifikasi Pengelolaan Hutan Bersama Masyarakat Lestari (PHBML) yang dikeluarkan oleh Lembaga Ekolabel Indonesia (LEI) pada tahun 2004 (Kelurahan Selopuro) dan 2007 (Desa Sejati, Desa Tirtosuworo, Desa Guwotirto, dan Kelurahan Girikikis).

Kecamatan Giriwoyo berjarak sekitar 47 km dari Kota Wonogiri, sedangkan Kecamatan Batuwarno berjarak $54 \mathrm{~km}$ dari Kota Wonogiri. Luas Kecamatan Giriwoyo adalah 10.060 ha dengan ketinggian sekitar 169 m dpl, sedangkan Kecamatan Batuwarno memiliki luas sekitar separuhnya yaitu 5.165 ha dengan ketinggian $274 \mathrm{~m}$ dpl. Kecamatan Batuwarno memiliki batas wilayah sebagai berikut yaitu: sebelah utara adalah Kecamatan Tirtomoyo dan Kecamatan Baturetno; sebelah barat adalah Kecamatan Baturetno dan Kecamatan Giriwoyo; sebelah timur adalah Kecamatan Tirtomoyo dan Kecamatan Karangtengah; sebelah selatan adalah Kecamatan Giriwoyo dan Kecamatan Karangtengah. Batas wilayah yang dimiliki Kecamatan Giriwoyo adalah: sebelah utara adalah Kecamatan Baturetno; sebelah barat adalah Kecamatan Karangtengah dan Kecamatan Batuwarno; sebelah timur adalah Kecamatan Giritontro dan Kecamatan Eromoko; sebelah selatan adalah Kabupaten Pacitan di Provinsi Jawa Timur (BPS Wonogiri, 2015).

Lokasi penelitian dapat diakses menggunakan jalan darat baik dengan kendaraan roda dua maupun roda empat. Untuk mencapai Kecamatan Batuwarno dapat dilakukan dengan menggunakan bis umum dari Kota Wonogiri ke jurusan Baturetno dengan ongkos sekitar Rp. 15.000,00 dan turun di Pasar Baturetno. Selanjutnya perjalanan dapat ditempuh dengan menggunakan ojek Rp. 13.000,00 atau Angkutan Pedesaan (Angkudes) dengan biaya Rp. 6.000,00. Kecamatan Giriwoyo dapat ditempuh menggunakan bus umum dari Kota Wonogiri ke jurusan Pacitan dengan biaya sekitar Rp. 17.000,00 dan turun di Persimpangan Giriwoyo. Selanjutnya untuk mencapai keempat desa/kelurahan lokasi penelitian dilakukan, dapat menggunakan angkudes atau ojek motor.

\section{Sejarah Hutan Rakyat Kabupaten Wonogiri}

Kabupaten Wonogiri merupakan wilayah yang didominasi perbukitan dengan batuan kapur sehingga memiliki tingkat kesuburan tanah relatif rendah. Hal ini menyebabkan tanaman pertanian khususnya pangan tidak dapat tumbuh dan berkembang dengan optimal. Tahun 1960-an, Wonogiri mengalami bencana kekeringan pada setiap musim kemarau dan di beberapa daerah terjadi banjir serta tanah longsor pada musim penghujan. Akibatnya pada musim kemarau terjadi paceklik, bahkan pada saat itu terjadi busung lapar akibat gagal panen karena sebagian besar sawah hanya mengandalkan air hujan sebagai sumber pengairan. Kemampuan bertani tanaman pertanian 
sudah dikerahkan oleh masyarakat, namun hasil yang diperoleh tidak sesuai dengan harapan. Tanaman singkong atau ubi kayu merupakan salah satu tanaman pertanian yang dapat tumbuh dengan baik. Singkong inilah yang diolah menjadi gaplek, sehingga makanan pokok sebagian masyarakat Wonogiri pada saat itu adalah nasi thiwul, yaitu gaplek yang diolah menjadi makanan pengganti nasi.

Berbagai pelatihan telah diselenggarakan oleh pemerintah untuk meningkatkan kemampuan petani dalam mengelola lahan pertanian namun tidak terjadi perbaikan. Kondisi ini menyebabkan beberapa tokoh masyarakat (kepala dusun) berupaya untuk mencari jalan keluar dari permasalahan yang selama ini menghimpit rakyatnya. Berbekal ilmu yang diperoleh dari berbagai pelatihan, para tokoh masyarakat ini kemudian mencoba menanam tanaman kayu di lahanlahan mereka dan lahan kas desa. Hal ini dilakukan karena mereka melihat dan mengamati bahwa tanaman kayu (jati dan mahoni) mampu tumbuh subur di desanya.

Para tokoh masyarakat kemudian mengajak masyarakat untuk mulai menanam tanaman jati dan mahoni, namun berbagai tanggapan diberikan oleh masyarakat. Sebagian besar masyarakat menolak ajakan tersebut karena mereka beranggapan bahwa tanaman kayu tidak dapat memenuhi kebutuhan pangan mereka, bahkan beberapa orang berkomentar bahwa meraka tidak dapat makan kayu. Petani tetap mengusahakan tanaman pertanian meskipun hasilnya tidak memadai.

Tindakan yang diambil petani sesuai dengan pernyataan Scott (1976) bahwa petani akan melakukan tindakan yang menurutnya aman dan dapat diandalkan daripada memperoleh keuntungan dalam jangka panjang, meskipun keuntungan yang akan diperoleh lebih besar dibandingkan sebelumnya. Petani tidak berani mengambil tindakan dengan menanam kayu di lahannya karena mereka takut akan adanya kegagalan yang berakibat tidak dapat memenuhi kebutuhan pangan keluarganya.

Penolakan petani tidak menyebabkan tokoh masyarakat ini mundur, mereka bahkan lebih aktif menanam tanaman kayu di setiap lahan kosong yang ada. Ternyata tanaman kayu yang ditanam menunjukkan pertumbuhan yang bagus bahkan sangat bagus dan beberapa tanaman sudah berbuah sehingga muncul banyak anakan di sekitarnya. Akibatnya, lahan yang semula gersang dan tandus mulai hijau karena ditumbuhi tanaman hutan.

Melihat keberhasilan para tokoh ini, banyak masyarakat yang mulai bertanya mengenai cara membudidayakan tanaman kayu. Tokoh masyarakat dengan senang hati mengajarkan cara budidaya tanaman kayu yang telah mereka lakukan. Semakin hari semakin banyak petani yang menanami lahannya dengan tanaman kayu.

Penanaman tanaman kayu oleh petani Wonogiri merupakan sebuah inovasi. Rogers (1995) menyatakan bahwa inovasi adalah suatu ide, gagasan, atau teknologi yang dipandang sebagai sesuatu hal yang baru oleh individu atau penggunanya. Sesuatu hal tersebut tidak harus merupakan ide, gagasan, atau tekonologi yang baru ditemukan, tetapi dapat berupa ide, gagasan, atau teknologi yang bagi penggunanya merupakan sesuatu hal yang baru. Budidaya tanaman bukan merupakan suatu hal yang baru bagi petani di Wonogiri karena mereka sudah bekerja sebagai petani puluhan tahun. Namun, komoditas kayu merupakan hal yang baru sehingga bagi mereka budidaya tanaman kayu merupakan sebuah inovasi.

Tidak banyak permasalahan yang ditemui oleh petani ketika mereka mulai membudidayakan tanaman kayu karena mereka memiliki pengalaman bercocok tanam yang cukup baik. Kegiatan penyuluhan juga berjalan dengan baik pada waktu itu. Bersama-sama dengan tokoh masyarakat, penyuluh kehutanan lapangan (PKL) juga memberikan penjelasan mengenai teknik budidaya tanaman kayu yang baik sehingga masyarakat semakin bersemangat menanam tanaman kayu.

Pemerintah juga memberikan bantuan berupa bibit tanaman kayu yang dapat diperoleh petani secara cuma-cuma melalui proyek penghijauan pada tahun 1980-an. Masyarakat diberi upah atas penanaman yang dilakukan dan semua biaya yang dibutuhkan untuk penanaman diberikan oleh pemerintah. Tujuan pemerintah adalah untuk mendorong masyarakat memanfaatkan lahan-lahan kosong dengan tanaman hutan yang bermanfaat untuk memperbaiki kondisi lingkungan. Jenis tanaman hutan yang pada waktu itu ditanam adalah jati, mahoni, akasia, dan trembesi.

\section{Hutan Rakyat di Kabupaten Wonogiri}

Hutan rakyat di Wonogiri merupakan hutan yang dikelola oleh masyarakat dan berada di lahan milik masyarakat. Luasan hutan rakyat relatif sempit, 
yaitu berkisar 0,03 ha sampai dengan 3,3 ha. Hal ini sesuai dengan pernyataan Hardjanto (2015) bahwa hutan rakyat memiliki luasan yang sempit. Hutan rakyat di Kabupaten Wonogiri lokasinya tersebar dan tidak dalam satu hamparan sehingga sering ditemui lahan hutan rakyat berada di desa atau dusun yang berbeda dengan tempat tinggal (rumah) petani.

Hutan rakyat di Kabupaten Wonogiri sebagian besar menerapkan sistem agroforestri, yaitu dalam hamparan lahan yang sama ditanami tanaman hutan dicampur dengan tanaman lain baik secara bersamaan maupun secara bergantian. Hutan rakyat di Kelurahan Selopuro didominasi oleh jenis jati dan mahoni. Namun beberapa petani yang memiliki lahan relatif subur mulai mengganti tanaman mahoni dengan jenis sengon. Hal ini dikarenakan sengon mulai memiliki pasar yang bagus sehingga memiliki harga jual cukup baik. Ini sesuai dengan pernyataan Hardjanto (2015) bahwa salah satu pertimbangan petani dalam memilih jenis tanaman kayu adalah ketersediaan pasar.

Hutan rakyat di Desa Sejati, Desa Guwotirto, Desa Tirtosuworo, dan Kelurahan Girikikis didominasi oleh jenis jati, mahoni, akasia, sonokeling, dan trembesi. Jenis-jenis inilah yang sejak awal telah diusahakan oleh petani. Jenis-jenis inilah yang mampu tumbuh dan berkembang dengan baik di lahan-lahan petani. Tanaman tumpang sari yang diusahakan di bawah tegakan merupakan jenis empon-empon dengan didominasi oleh kunyit.

Sistem agroforestri banyak dipilih oleh petani karena sistem ini dapat memberikan pendapatan kepada petani berupa pendapatan mingguan, bulanan, dan puluhan tahun. Petani hutan rakyat Wonogiri memperoleh pendapatan mingguan dari cabai rawit, pendapatan bulanan dari palawija, dan pendapatan puluhan tahun dari tanaman kayu. Petani juga memperoleh pakan ternak dari hutan rakyat berupa rumput gajah sehingga tidak perlu mencari rumput ke tempat-tempat lain yang jauh dari rumah. Hal ini menguntungkan petani, terutama ibu-ibu yang salah satu tugasnya adalah mencari rumput sebagai pakan ternak. Hal ini sesuai dengan penelitian Hlaing \& Inoue (2013) di Myanmar yang menunjukkan bahwa manfaat ekonomi yang diperoleh petani dari hutan rakyat pola agroforestri meskipun tidak banyak namun dapat meningkatkan penghasilan petani. Penghasilan ini dapat digunakan untuk memenuhi kebutuhan keluarga yang memiliki tanggungan jiwa sebesar 4-5 orang.
Selain itu, petani terutama para ibu dapat mengurangi pengeluaran rumah tangganya karena beberapa bahan makanan dapat diperoleh dari hutannya, misalnya sayuran, cabai rawit, singkong, jagung, dan bumbu dapur (kunyit, jahe, lengkuas). Pengeluaran lain yang dapat dikurangi petani adalah pengeluaran untuk pembelian bahan bakar seperti gas dan minyak tanah. Petani memanfaatkan ranting kayu rakyat sebagai kayu bakar dan digunakan untuk keperluan memasak makanan. Selain itu, ibu rumah tangga juga memiliki waktu luang untuk melakukan kegiatan-kegiatan di luar pertanian. Hal ini dimungkinkan karena hutan rakyat pola agroforestri dapat menyediakan pakan ternak sehingga dapat menghemat waktu. Jadi, meskipun pendapatan yang diperoleh dari hutan rakyat relatif kecil, namun hutan rakyat dapat membantu petani mengurangi pengeluaran rumah tangganya.

\section{Karakteristik Petani Hutan Rakyat}

Karakteristik petani hutan merupakan penciri yang dimiliki oleh masing-masing responden yang mencakup pendidikan formal, pendidikan non formal, pengalaman berusahatani hutan rakyat, pendapatan, dan jumlah tanggungan keluarga. Tabel 1 menunjukkan karakteristik petani hutan rakyat di Kabupaten Wonogiri.

Sebagian besar petani hutan rakyat $(76,42 \%)$ menempuh pendidikan formal berkisar 6-10 tahun, artinya sebagian besar petani hutan rakyat telah menamatkan Sekolah Dasar (SD) hingga Sekolah Menengah Pertama (SLTP). Hal ini menunjukkan bahwa sebagian besar petani menyadari arti pentingnya pendidikan formal untuk menunjang kehidupan mereka. Mereka menyadari bahwa pengetahuan yang diperoleh dari bangku sekolah dapat digunakan untuk memperbaiki tingkat penghidupannya. Kondisi lahan pertanian di Kabupaten Wonogiri relatif kurang subur sehingga untuk dapat bertahan hidup, masyarakat harus bekerja keras mengolah lahannya agar menghasilkan. Berbeda dengan petani di Bogor yang memiliki tingkat pendidikan rendah (Anshori, 2012; Pratamaningtyas, 2013). Petani di Bogor belum menganggap pendidikan formal menjadi suatu kebutuhan karena lahan di Bogor yang relatif subur. Lahan yang subur mampu memberikan hasil yang relatif memuaskan, terutama untuk tanaman pertanian sehingga kebutuhan hidup dapat tercukupi tanpa perlu menempuh pendidikan formal yang memadai. 
Tabel 1. Deskripsi Karakteristik Petani Hutan Rakyat di Kabupaten Wonogiri, 2016

\begin{tabular}{|c|c|c|c|}
\hline No & Karakteristik & Kategori & Persentase $(\%)$ \\
\hline \multirow[t]{4}{*}{1} & Pendidikan Formal (tahun) & Rendah (0-5) & 9,76 \\
\hline & & Sedang (6-10) & 76,42 \\
\hline & & Tinggi (11-16) & 13,82 \\
\hline & Rataan: 7,25 & & \\
\hline \multirow[t]{4}{*}{2} & Pendidikan Non Formal (jam) & Rendah (0-23) & 96,75 \\
\hline & & Sedang (24-48) & 2,85 \\
\hline & & Tinggi 49-72) & 0,41 \\
\hline & Rataan: 1,24 & & \\
\hline \multirow[t]{4}{*}{3} & Pengalaman (tahun) & Rendah (1-19) & 43,09 \\
\hline & & Sedang (20-37) & 44,31 \\
\hline & & Tinggi (38-56) & 12,60 \\
\hline & Rataan: 22,99 & & \\
\hline \multirow[t]{4}{*}{4} & Pendapatan (X Rp. $10.000,00$ per bulan) & Rendah $(47,9-152,5)$ & 76,83 \\
\hline & & Sedang $(152,5-257,1)$ & 20,33 \\
\hline & & Tinggi $(257,1-361,7)$ & 2,85 \\
\hline & Rataan: 126,9 & & \\
\hline \multirow[t]{4}{*}{5} & Tanggungan Keluarga (jiwa) & Kecil (1-2) & 37,40 \\
\hline & & Sedang (3-4) & 47,15 \\
\hline & & Besar (5-6) & 15,45 \\
\hline & Rataan: 3 & & \\
\hline
\end{tabular}

Pendidikan non formal yang dimiliki petani hutan rakyat di Wonogiri tergolong rendah $(96,75 \%)$, yaitu berkisar 0-23 jam. Sebagian besar petani bahkan tidak pernah mengikuti pelatihan/kursus terkait hutan rakyat. Pendidikan non formal yang dimaksud di sini adalah pelatihan atau kursus terkait dengan hutan rakyat dalam tiga tahun terakhir yang diikuti petani. Hal ini sangat disayangkan karena terjadi kemunduran dalam hal pemberian pelatihan/kursus bagi petani terkait hutan rakyat. Dahulu, ketika hutan rakyat Wonogiri akan disertifikasi, banyak pelatihan yang diselenggarakan oleh para pihak (LSM, Dinas Kehutanan dan Perkebunan, Departeman Kehutanan/ KLHK) untuk meningkatkan kemampuan petani dalam mengelola hutannya. Pelatihan tersebut antara lain adalah pembuatan peta secara partisipatif, pengukuran kayu, pembuatan dokumen-dokumen pengelolaan hutan, budidaya tanaman hutan dan tumpang sari, pengolahan kayu rakyat). Beberapa petani bahkan menyatakan bahwa kegiatan penyuluhan yang bertujuan untuk meningkatkan kemampuan petani sudah tidak ada.

Ketiadaan pelatihan/kursus terkait hutan rakyat dapat disebabkan karena para pihak merasa bahwa petani sudah memiliki kemampuan untuk mengelola hutannya dengan baik sehingga tidak memerlukan pelatihan/kursus. Hal ini sebenarnya tidak sesuai dengan pernyataan yang disampaikan oleh Asngari (2008) yang menyatakan bahwa salah satu falsafah penyuluhan adalah kontiny. Berkelanjutan mengandung makna bahwa dunia selalu berkembang, manusia berkembang, ilmu pengetahuan dan teknologi berkembang, sehingga kegiatan penyuluhan harus dapat menyesuaikan dengan perkembangan yang ada. Perkembangan tersebut mencakup materi yang disajikan, cara penyajian, dan alat bantu penyajian. Materi penyuluhan (baik berupa pelatihan atau kursus) akan selalu mengalami perkembangan sesuai dengan kebutuhan petani hutan rakyat. Saat ini petani sudah mampu mengelola hutannya dengan baik, namun petani masih mempunyai permasalahan lain misalnya masih rendahnya kemampuan petani untuk mengolah hasil hutannya sehingga mereka dapat menjual produknya dalam bentuk barang jadi atau setengah jadi sehingga petani akan memperoleh nilai tambah dari kayu rakyat. Kegiatan penyuluhan menurut Jarvis (2004) merupakan pendidikan sepanjang hidup (lifelong learning) sehingga tidak ada kata berhenti 
dalam penyuluhan. Perkembangan akan selalu terjadi sehingga kebutuhan petani hutan rakyat akan selalu berkembang.

Penelitian yang dilakukan Yadav et al., (2015) di Nepal menunjukkan bahwa pendidikan dan pelatihan yang dilakukan oleh LSM mampu meningkatkan kemampuan petani miskin dan golongan marginal sehingga mereka dapat menduduki posisi pimpinan di lembaga pengelola hutan kemasyarakatan. Kedudukan ini memungkinkan petani dan kaum marjinal dapat menyampaikan aspirasinya yang berdampak pada lahirnya kebijakan yang lebih pro pada kaum miskin dan marginal.

Pengalaman yang dimiliki oleh petani dalam mengelola hutan rakyat cukup lama (rerata 22,99 tahun), bahkan sebanyak $56,91 \%$ petani telah mengelola hutannya lebih dari 20 tahun. Banyaknya pengalaman yang dimiliki petani karena sejak kecil mereka telah diajak dan diajari orang tuanya untuk melakukan budidya tanaman kayu dan tanaman pertanian. Keluarga merupakan sumber tenaga kerja bagi petani dalam mengelola lahannya, sejak kecil anak petani sudah dilibatkan sehingga mereka memiliki pengetahuan dan ketrampilan dalam hal budidaya tanaman. Manfaat yang mereka rasakan dari kegiatan budidaya tanaman menyebabkan mereka hingga saat ini tetap melakukan budidaya tanaman, termasuk tanaman hutan. Para tetua (orang tua dan nenek moyang) merupakan sumber pengetahuan dan ketrampilan bagi keturunannya.

Pendapatan yang diperoleh petani hutan rakyat dari berbagai sumber termasuk rendah. Sebagian besar petani $(76,83 \%)$ memiliki pendapatan tergolong rendah yaitu berkisar Rp 479.000,00 s.d Rp 1.525.000,00 setiap bulannya, sedangkan pendapatan rata-rata petani hutan rakyat adalah Rp 1.269.191,00. Pendapatan ini lebih kecil dibandingkan dengan Upah Minimum Kabupaten Wonogiri, yaitu sebesar Rp 1.293.000,00. Pendapatan yang relatif kecil ini harus dikelola petani dengan baik sehingga harus dapat mencukupi kebutuhan keluarganya. Petani menyatakan bahwa adanya hutan rakyat dapat membantu mereka, terutama untuk mengurangi pengeluaran rumah tangga seharihari. Hutan rakyat mampu menyediakan sayur-mayur, kayu bakar, obat-obatan tradisional, dan pakan ternak. Berkurangnya pengeluaran rumah tangga sangat membantu petani, terutama petani berpendapatan rendah.

Jumlah tanggungan keluarga petani hutan rakyat di Wonogiri $(47,15 \%)$ tergolong sedang, yaitu berkisar 3-4 orang (rerata 3). Jumlah ini tergolong kecil karena hampir semua penduduk yang berusia produktif (18-58 tahun) merantau ke kota dengan berbagai tujuan, antara lain bekerja dan bersekolah. Jumlah tanggungan keluarga yang kecil menyebabkan jumlah pendapatan yang kecil dapat digunakan untuk mencukupi kebutuhan rumah tangga. Jumlah tanggungan keluarga terbesar adalah 6 orang. Jumlah ini bukan merupakan jumlah keluarga inti petani karena biasanya petani yang berusia lanjut hanya tinggal bersama isteri atau ditemani cucu (usia sekolah) karena anak-anak mereka merantau ke kota. Jumlah tanggungan keluarga yang relatif kecil juga menjadi pertimbangan bagi petani untuk mengkonversi lahan pertaniannya menjadi hutan rakyat. Untuk mengelola lahan pertanian diperlukan tenaga kerja yang cukup banyak. Jumlah anggota keluarga yang tidak memadai untuk mengelola lahan pertanian mengharuskan petani mempekerjakan orang lain dan hal ini akan menambah pengeluaran petani. Untuk itu maka konversi lahan menjadi hutan rakyat merupakan solusi terbaik bagi petani saat ini yang memiliki keterbatasan tenaga kerja.

\section{Persepsi Petani tentang Hutan Rakyat}

Asngari (1984) berdasarkan beberapa pakar menyatakan bahwa persepsi adalah interpretasi individu akan makna sesuatu baginya dalam kaitan dengan "dunia"nya. Orang bertindak sebagian dilandasi oleh persepsi mereka pada suatu situasi sehingga persepsi/ pengertian individu terhadap lingkungannya merupakan faktor penting dan sangat menentukan tindakan yang dilakukannya.

Litterer (Asngari, 1984) menyatakan bahwa pembentukan persepsi terdiri dari tiga mekanisme yaitu selectivity, closure, dan interpretation. Informasi yang sampai kepada seseorang menyebabkan individu yang bersangkutan membentuk persepsi, dimulai dengan pemilihan atau menyaringnya, kemudian informasi yang masuk tersebut disusun menjadi kesatuan yang bermakna, dan akhirnya terjadilah interpretasi mengenai fakta keseluruhan informasi itu. Fase interpretasi sangat dipengaruhi oleh pengalaman masa silam.

Rata-rata persepsi petani di Kabupaten Wonogiri terhadap pengelolaan hutan rakyat pola agroforestri tergolong tinggi, yang ditunjukkan oleh nilai rata-rata 3,14 (Skala Likert). Gambaran persepsi petani terhadap pengelolaan hutan rakyat (Gambar 1). 


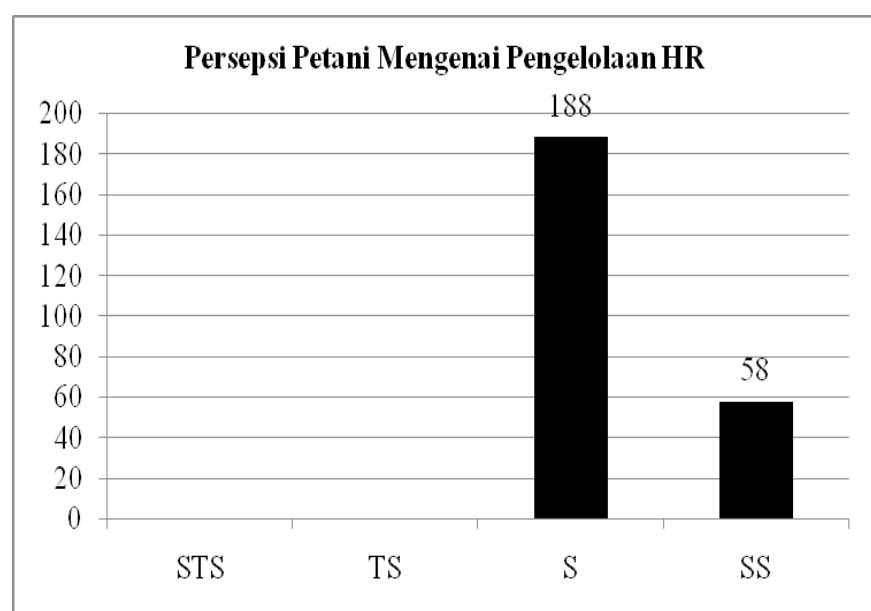

Keterangan:

SR = Sangat Rendah (1-1,60);

$\mathrm{R} \quad=$ Rendah $(1,61-2,20)$;

$\mathrm{S} \quad=$ Sedang $(2,21-2,80)$;

$\mathrm{T}=$ Tinggi $(2,81-3,40)$;

ST = Sangat Tinggi $(3,41-4,00)$

Gambar 1. Distribusi Persepsi Petani mengenai Pengelolaan Hutan Rakyat di Kabupaten Wonogiri, 2016

Menurut petani, hutan rakyat pola agroforestri adalah lahan milik yang ditanami dengan tanaman kayu dan tanaman pertanian semusim. Jenis tanaman yang ditanam harus disesuaikan dengan kondisi lahan. Saat ini tanaman yang ditanam adalah didominasi jati.

Hutan rakyat sangat sesuai dengan kondisi Wonogiri yang memiliki lahan berkapur dan relatif tandus. Selain itu, pola agroforestri sangat sesuai untuk petani dengan lahan sempit. Masyarakat Wonogiri merupakan masyarakat perantau sehingga yang tinggal di desa adalah para orang usia lanjut dan anak-anak kecil yang masih sekolah di Sekolah Dasar hingga Sekolah Menengah Atas. Hal ini menyebabkan terbatasnya jumlah tenaga kerja di desa. Hutan rakyat pola agroforestri tidak membutuhkan curahan tenaga kerja yang banyak sehingga sangat sesuai dengan terbatasnya tenaga kerja.

Petani sudah memahami teknik budidaya tanaman hutan karena pada dasarnya hampir sama dengan tanaman pertanian yang sebelumnya telah mereka kelola. Kemampuan mereka membudidayakan tanaman diperoleh dari nenek moyangnya. Petani juga menyadari bahwa kualitas kayu akan menentukan harga jual kayu sehingga bibit unggul juga diperlukan dalam penanaman tanaman kayu.

Pernyataan-pernyataan yang disampaikan kepada petani adalah pernyataan mengenai pengertian hutan rakyat, kegiatan penyiapan lahan, kegiatan penanaman, kegiatan pemeliharaan, kegiatan pemanenan, dan pemasaran kayu rakyat. Tanggapan petani terhadap pernyataan-pernyataan mengenai pengelolaan hutan rakyat pola agroforestri disajikan pada Tabel 2. Pengelolaan hutan rakyat terdiri dari kegiatan penyiapan lahan, penanaman, pemeliharaan, pemanenan, pengolahan, dan pemasaran. Data menunjukkan bahwa sebagian besar petani menyepakati pernyataan-pernyataan yang ada. Namun demikian, pada pernyataan nomor 5 dan 13 terdapat nilai yang hampir berimbang antara yang menyepakati dan tidak menyepakati pernyataan yang diberikan. Petani beranggapan bahwa pengelolaan hutan rakyat dilakukan secara intensif seperti halnya tanaman pertanian semusim. Petani memaknai bahwa tanaman kayu memerlukan perawatan sama intensifnya dengan tanaman semusim.

Tabel 2. Distrubusi Tanggapan Petani mengenai Pengelolaan Hutan Rakyat Pola Agroforestri di Kabupaten Wonogiri, 2016

\begin{tabular}{ccc}
\hline $\begin{array}{c}\text { Pernyataan } \\
\text { No. }\end{array}$ & $\begin{array}{c}\text { S dan SS } \\
(\%)\end{array}$ & $\begin{array}{c}\text { TS dan STS } \\
(\%)\end{array}$ \\
\hline 1 & 91,87 & 8,13 \\
2 & 100,00 & 0,00 \\
3 & 100,00 & 0,00 \\
4 & 92,28 & 7,72 \\
5 & 57,32 & 42,68 \\
6 & 91,87 & 8,13 \\
7 & 100,00 & 0,00 \\
8 & 100,00 & 0,00 \\
9 & 97,15 & 2,85 \\
10 & 89,84 & 10,16 \\
11 & 98,78 & 1,22 \\
12 & 87,80 & 12,20 \\
13 & 53,25 & 46,75 \\
14 & 85,77 & 14,23 \\
15 & 97,56 & 2,44 \\
16 & 89,43 & 10,57 \\
17 & 100,00 & 0,00 \\
\hline
\end{tabular}

\begin{tabular}{lll}
\hline Keterangan: & SS & $=$ Sangat Setuju; \\
S & $=$ Setuju; \\
TS & $=$ Tidak Setuju; \\
STS & $=$ Sangat Tidak setuju
\end{tabular}

Persepsi petani mengenai hal tersebut tidak terlepas dari informasi yang diterima petani mengenai 
pengelolaan tanaman kayu. Petani lebih banyak menerima informasi mengenai pengelolaan hutan rakyat dari nenek moyangnya (terutama orang tua). Informasi inilah yang kemudian oleh petani disusun menjadi sebuah kesatuan yang bermakna hingga munculah interpretasi dalam diri petani bahwa hutan rakyat perlu perawatan yang intensif, mulai dari pemupukan, penyiangan, pendangiran, enanggulangan hama penyakit.

Selain itu, pengalaman petani sangat menentukan interpretasi petani mengenai hutan rakyat pola agroforestri. Sebagian besar petani hutan rakyat pada awalnya merupakan petani tanaman semusim sehingga pengalaman bertani tanaman semusim menjadi acuan bagi dirinya dalam mengelola tanaman kayunya. Hal ini menyebabkan petani beranggapan bahwa tanaman kayu memerlukan perawatan yang intensif. Persepsi/pengertian petani menunjukkan bahwa tanaman semakin dirawat maka pertumbuhannya akan semakin bagus. Faktanya, tanaman kayu merupakan tanaman yang tidak memerlukan perawatan yang intensif. Tanaman kayu hanya memerlukan pemupukan pada 2 tahun pertama (setiap 6 bulan) dan selanjutnya mampu hidup mandiri. Perawatan yang intensif hanya akan membebani petani dengan biaya-biaya yang sesungguhnya tidak diperlukan, misalkan pembelian pupuk, insektisida, dan lainnya. Tanaman kayu setelah berumur 2 tahun biasanya akan mampu menghidupi dirinya sendiri sehingga tidak memerlukan peratawan lagi. Jika diperlukan, pada waktu-waktu tertentu diperlukan penyiangan gulma, dan itu pun dilakukan ditujukan untuk tanaman tumpang sarinya, bukan untuk tanaman kayu.

Petani juga beranggapan bahwa menanam tanaman kayu serapat mungkin akan memberikan keuntungan yang besar. Hal ini kurang tepat karena tanaman kayu membutuhkan ruang yang lebih besar untuk tumbuh dibandingkan dengan tanaman semusim. Tanaman jati misalnya, membutuhkan jarak tanam 3 m X 3 m. Hal ini diperlukan agar tanaman memiliki ruang tumbuh yang leluasa bagi dirinya untuk tumbuh ke samping sehingga tanaman akan memiliki diamater yang besar dan mempunyai nilai jual tinggi. Petani masih beranggapan bahwa semakin banyak jumlah tanamannya maka akan semakin menguntungkan. Hal ini kurang tepat karena harga kayu sangat ditentukan oleh ukuran diamater kayu, semakin besar diameter maka akan semakin tinggi harga jualnya.
Rata-ratapersepsipetanidiKabupaten Wonogiri terhadap manfaat hutan rakyat pola agroforestri adalah tinggi, yang ditunjukkan oleh nilai rata-rata 3,09 (Skala Likert). Hal ini sesuai dengan penelitian Suryaningsih et al., (2012) di Kabupaten Purworejo yang menunjukkan bahwa persepsi masyarakat adalah hutan rakyat telah mampu berfungsi dengan baik (secara ekonomi, ekologi, dan sosial). Berfungsinya hutan rakyat dengan baik ditunjukkan oleh fakta bahwa lahan yang dulu gersang kini menjadi hijau, kebutuhan air tercukupi sehingga tidak mengalami kekeringan lagi pada musim kemarau, kebutuhan kayu terpenuhi, dan keberhasilan dalam memenangkan perlombaan bidang penghijauan. Gambaran persepsi petani terhadap manfaat hutan rakyat (Gambar 2).

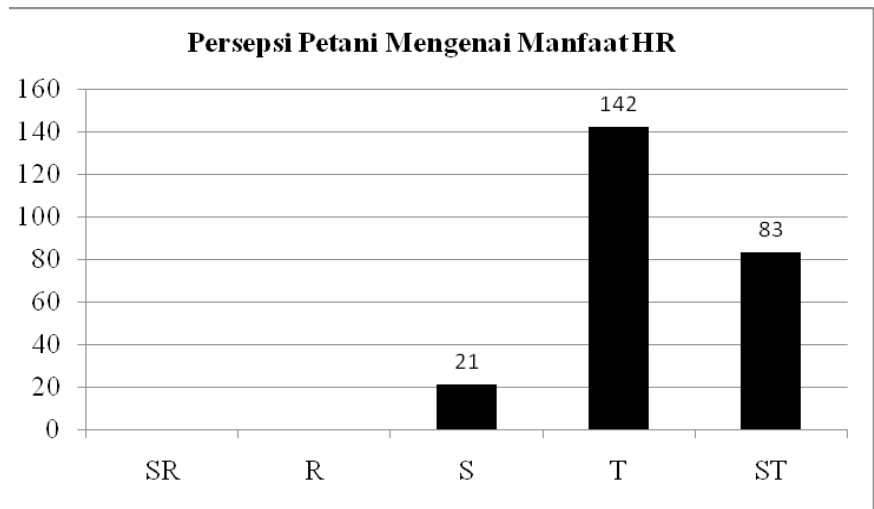

Keterangan:

$$
\begin{array}{ll}
\mathrm{SR} & =\text { Sangat Rendah }(1-1,60) \\
\mathrm{R} & =\text { Rendah }(1,61-2,20) \\
\mathrm{S} & =\text { Sedang }(2,21-2,80) \\
\mathrm{T} & =\text { Tinggi }(2,81-3,40) \\
\mathrm{ST} & =\text { Sangat Tinggi }(3,41-4,00)
\end{array}
$$

Gambar 2. Distribusi Persepsi Petani mengenai Manfaat Hutan Rakyat di Kabupaten Wonogiri, 2016

Petani merasa bahwa hutan rakyat pola agroforestri memberikan banyak manfaat bagi mereka. Manfaat yang telah dirasakan antara lain adalah adanya tambahan penghasilan. Penelitian yang dilakukan oleh Rahut et al., (2015) menunjukkan bahwa hutan rakyat mampu meningkatkan penghasilan petani sebesar $5-12 \%$ dan mendukung ketahanan pangan (food security) sebesar 12-19\% di Bhutan. Penelitian Moktan et al., (2016) di Kabupaten Haa dan Paro (Bhutan bagian barat) menunjukkan bahwa hutan rakyat mampu meningkatkan penghasilan petani. Peningkatan penghasilan diperoleh petani dari penjualan kayu, jamur, daun, dan kayu bakar. Besarnya penghasilan tambahan sangat bervariasi antara petani kaya dan 
petani miskin. Penelitian Suprayitno et al., (2012) menunjukkan bahwa hutan kemiri rakyat yang berada di Kabupaten Maros Sulawesi Selatan menjadi salah satu sumber pendapatan bagi masyarakat. Buah kemiri memiliki daya simpan yang tinggi sehingga dapat disimpan untuk dijual ketika petani membutuhkan uang tunai. Pendapatan yang diperoleh petani sekitar $13 \%$ dari total pendapatannya.

Petani di Wonogiri juga menyatakan bahwa keberadaan hutan rakyat pola agroforestri dapat mengurangi pengeluaran mereka. Hutan rakyat merupakan salah satu sumber energi (kayu bakar yang berasal dari ranting atau cabang yang berjatuhan), sumber pangan (sayur, cabai rawit), sumber obat (tanaman rimpang), dan pakan ternak (rumput gajah). Hal ini seperti yang dikemukakan oleh Adhikari et al., (2007)yangmelakukan penelitian di Nepal bahwahutan rakyat mampu meningkatkan kesejahteraan petani. Pemanenan pohon dilakukan secara berkelompok setiap tahun, yaitu pada Bulan Februari. Petani dapat memanfaatkan cabang dan ranting-ranting kering sebagai bahan bakar untuk kebutuhannya sendiri. Pemungutan hasil hutan bukan kayu (non timber forest products/ NTFPs) berupa tanaman obat untuk kebutuhan sendiri (subsisten). Kelompok membuat aturan yang melarang pemungutan NTFPs untuk keperluan komersial.

Manfaat lain yang diperoleh petani adalah tersedianya air bersih, dan munculnya beberapa hewan (kera, burung, lebah) yang menjadikan hutan rakyat sebagai habitatnya. Hal ini menunjukkan bahwa manfaat ekologi sangat dirasakan oleh petani. Penelitian Djamhuri (2008) di Kabupaten Gunung Kidul menunjukkan bahwa manfaat yang diperoleh dari hutan rakyat bukan hanya dirasakan oleh petani hutan saja melainkan juga dirasakan oleh masyarakat secara umum. Petani hutan rakyat menyisihkan sebagian hasil penjualan kayu rakyat untuk kas desa. Dana ini nantinya dapat digunakan untuk pengembangan desa.

Pernyataan-pernyataan yang disampaikan kepada petani adalah pernyataan mengenai manfaat ekonomi, manfaat ekologi, dan manfaat sosial hutan rakyat pola agroforestri. Tanggapan petani terhadap pernyataan-pernyataan mengenai manfaat hutan rakyat pola agroforestri (Tabel 3).

Data pada Tabel 3 menunjukkan bahwa sebagian besar petani menyepakati pernyataanpernyataan yang ada, namun pada pernyataan 5 terdapat nilai yang berimbang antara menyepakati dan
Tabel 3. Distribusi Tanggapan Petani mengenai Manfaat Hutan Rakyat Pola Agroforestri di Kabupaten Wonogiri, 2016

\begin{tabular}{ccc}
$\begin{array}{c}\text { Pernyataan } \\
\text { No. }\end{array}$ & $\begin{array}{c}\text { S dan SS } \\
(\%)\end{array}$ & $\begin{array}{c}\text { TS dan STS } \\
\mathbf{( \% )}\end{array}$ \\
\hline 1 & 91,87 & 8,13 \\
2 & 100,00 & 0,00 \\
3 & 100,00 & 0,00 \\
4 & 92,28 & 7,72 \\
5 & 57,32 & 42,68 \\
\hline
\end{tabular}

tidak menyepakati pernyataan yang diberikan. Persepsi petani menunjukkan bahwa keberadaan hutan rakyat belum sepenuhnya mampu mendorong tumbuh dan berkembangnya industri kayu dan bukan kayu (non kayu). Pemahaman ini didasari karena petani belum menyadari bahwa hutan rakyat saat ini telah menjadi pemasok bahan baku kayu untuk industri kayu di Indonesia. Hal ini sebagaimana yang disampaikan BRIK (2010) penggunaan bahan baku dari hutan rakyat pada tahun 2011 mencapai 50\%, meningkat dari tahun-tahun sebelumnya yang berkisar 40\%. Industri pengolah kayu membutuhkan kayu rakyat sebagai bahan bakunya, bahkan pada tahun 2012 telah berdiri pabrik barecore di Wonogiri yang bahan bakunya berasal dari kayu rakyat. Keberadaan industri ini membuka lapangan pekerjaan bagi masyarakat sekitar. Persepsi petani yang rendah juga dapat disebabkan karena petani kurang memperoleh informasi mengenai rantai pemasaran kayu rakyatnya. Petani tidak menyadari bahwa kebutuhan kayu rakyat semakin besar sehingga seharusnya kedudukan mereka sangat penting dalam industri pengolahan kayu. Ketiadaan atau terbatasnya informasi ini menyebabkan posisi tawar petani masih rendah sehingga petani hanya berperan sebagai penerima harga (price taker) dalam perdagangan kayu rakyat. Awang et al., (2002) dan Hardjanto (2003) dalam penelitiannya menunjukkan bahwa dalam sistem penjualan kayu rakyat, posisi tawar petani rendah karena seringkali harga ditentukan oleh pembeli. Diduga rentabilitas usaha pengelolaan hutan rakyat sebagian besar tidak diterima petani tetapi diterima oleh pedagang perantara, sebab pola distribusi (tata niaga) skenarionya memang dibuat oleh pedagang dan jaringan pedagang. 


\section{Hubungan Karakteristik Petani dengan Persepsi Petani tentang Hutan Rakyat Pola Agroforestri}

Karakteristik petani yang diamati pada penelitian ini adalah pendidikan formal, pendidikan non formal, pengalaman, pendapatan, dan jumlah tanggungan keluarga (Tabel 4). Untuk mengetahui hubungan antara karakterisk petani dan persepsi petani mengenai hutan rakyat pola agroforestri digunakan uji korelasi Rank Spearman.

\section{Tabel 4. Nilai Koefisien Hubungan Karakteristik Petani dengan Persepsi Petani tentang Hutan Rakyat Pola Agroforestri di Kabupaten Wonogiri, 2016}

\begin{tabular}{llc}
\hline \multirow{2}{*}{ Karakteristik Petani } & \multicolumn{2}{c}{ Persepsi petani } \\
\cline { 2 - 3 } & $\begin{array}{c}\text { Pengelolaan } \\
\text { HR }\end{array}$ & $\begin{array}{c}\text { Manfaat } \\
\text { HR }\end{array}$ \\
\hline Pendidikan Formal & $0,132^{*}$ & $-0,016$ \\
Pendidikan Non Formal & $0,524 * *$ & 0,110 \\
Pengalaman & 0,108 & 0,075 \\
Pendapatan & 0,091 & $-0,114$ \\
Jumlah Tanggungan & $-0,029$ & $-0,199^{* *}$ \\
Keluarga &
\end{tabular}

Keterangan:

** $\quad=$ korelasi sangat nyata pada taraf $\alpha=1 \%$;

* $\quad=$ korelasi nyata pada taraf $\alpha=5 \%$

Pendidikan formal berkorelasi nyata pada taraf $\alpha \leq 5 \%$ dengan persepsi petani mengenai pengelolaan hutan rakyat. Semakin tinggi tingkat pendidikan formal petani maka akan semakin tinggi persepsinya mengenai pengelolaan hutan rakyat pola agroforestri. Petani dengan tingkat pendidikan formal yang tinggi akan memiliki wawasan yang lebih luas dibandingkan petani lainnya. Wawasan yang luas akan membuat petani lebih terbuka pada inovasi. Hutan rakyat pola agroforestri merupakan sebuah inovasi bagi petani. Rogers (1995) menyatakan bahwa inovasi adalah suatu ide, gagasan, atau teknologi yang dipandang sebagai sesuatu hal yang baru oleh individu atau penggunanya. Sesuatu hal tersebut tidak harus merupakan ide, gagasan, atau tekonologi yang baru ditemukan, tetapi dapat berupa ide, gagasan, atau teknologi yang bagi penggunanya merupakan sesuatu hal yang baru. Budidaya tanaman bukan merupakan suatu hal yang baru bagi petani di Wonogiri karena mereka sudah bekerja sebagai petani puluhan tahun, namun komoditas kayu merupakan hal yang baru sehingga bagi mereka budidaya tanaman kayu merupakan sebuah inovasi.

Pendidikan formal berkorelasi negatif (meskipun sangat lemah) dengan persepsi petani mengenai manfaat hutan rakyat pola agroforestri. Hal ini disebabkan karena petani dengan tingkat pendidikan formal lebih tinggi memilih pekerjaan utama di luar sektor pertanian (hutan rakyat) sehingga manfaat secara langsung tidak mereka rasakan, meskipun manfaat ekologi (ketersediaan air dan udara bersih) turut mereka nikmati. Hal ini sejalan dengan penelitian Tologbonse et al., (2013) di Nigeria yang menyatakan bahwa tingkat pendidikan yang tinggi membuat mereka memiliki kesempatan untuk bekerja di sektor lain dengan gaji yang lebih baik dibandingkan menjadi petani.

Pendidikan non formal berkorelasi sangat nyata pada taraf $\alpha \leq 1 \%$ dengan persepsi petani mengenai pengelolaan hutan rakyat. Semakin tinggi tingkat pendidikan formal petani maka persepsinya akan semakin tinggi dan selanjutnya akan semakin positif memaknai pengelolaan hutan rakyat pola agroforestri. Sejak awal pembangunan hutan rakyat, petani memperoleh pengetahuan dan ketrampilan mengenai budidaya tanaman kayu dari para tokoh masyarakat. Tokoh masyarakat menanam tanaman kayu di lahan miliknya sehingga petani dapat melihat dan mengamati tumbuhnya tanaman tersebut dengan baik. Melalui pendekatan ini maka persepsi petani berubah, yang semula menganggap tanaman kayu tidak dapat dibudidayakan di Wonogiri. Selain tokoh masyarakat, Penyuluh Kehutanan Lapangan (PKL) pada awal pembangunan hutan rakyat bersama dengan pemda melakukan kegiatan penyuluhan terkait budidaya tanaman kayu kepada masyarakat.

Pendidikan non formal memiliki korelasi positif(meskipun sangat lemah) dengan persepsi petani mengenai manfaat hutan rakyat pola agroforestri. Semakin tinggi pendidikan non formal yang dimiliki petani maka akan semakin tinggi persepsinya mengenai hutan rakyat pola agroforestri. Pendidikan non formal dapat meningkatkan kemampuan petani dalam mengelola hutannya sehingga hasilnya dapat lebih baik. Melalui teknik budidaya tanaman yang baik maka tumbuhan kayu dan semusim yang ditanam akan tumbuh secara optimal dan akan memiliki nilai jual yang lebih tinggi. Hal ini dapat meningkatkan penghasilan keluarga petani sehingga secara ekonomi manfaat tersebut dapat dirasakan petani.

Jumlah tanggungan keluarga berkorelasi 
sangat nyata pada taraf $\alpha \leq 1 \%$ dengan persepsi petani mengenai manfaat hutan rakyat. Nilai korelasi yang bertanda negatif menunjukkan bahwa semakin banyak jumlah tanggungan keluarga petani maka persepsi petani mengenai manfaat hutan rakyat akan semakin rendah. Hal ini disebabkan karena hutan rakyat belum mampu menjadi sumber mata pencaharian utama bagi petani sehingga manfaat ekonominya belum dirasakan oleh petani, khususnya petani yang memiliki jumlah tanggungan keluarga banyak. Hutan rakyat pola agroforestri tidak membutuhkan curahan tenaga yang besar sehingga tidak cukup menciptakan lapangan pekerjaan bagi anggota keluarga petani yang berjumlah banyak. Penelitian Hlaing \& Inoue (2013) di Myanmar menunjukkan bahwa manfaat ekonomi yang diperoleh petani dari hutan rakyat pola agroforestri meskipun tidak banyak namun dapat meningkatkan penghasilan petani. Penghasilan ini dapat digunakan untuk memenuhi kebutuhan keluarga yang memiliki tanggungan jiwa sebesar 4-5 orang.

Jumlah tanggungan keluarga juga berkorelasi negatif (meskipun sangat lemah) dengan persepsi petani mengenai pengelolaan hutan rakyat pola agroforestri. Hal ini dapat terjadi karenajumlah anggota keluarga yang cukup besar membuat petani berharap hutannya dapat memberikan manfaat ekonomi lebih besar. Akibatnya, kaidah-kaidah pengelolaan hutan yang baik tidak dilakukan, mulai dari penggunaan bibit unggul, pemupukan (hingga tahun kedua), penjarangan, pemangkasan, pengendalian hama penyakit, dan pemanenan yang baik. Pemupukan dianggap sebagai biaya sehingga tidak dilakukan. Pemanenan juga sering dilakukan ketika tanaman belum sampai daurnya karena adanya kebutuhan yang harus dipenuhi. Penanaman dilakukan dengan sangat rapat tanpa mempertimbangkan jarak tanam sehingga tanaman kayu tidak memiliki ruang tumbuh yang memadai. Hal yang berbeda ditemukan oleh Kallio et al., (2011) di Kalimantan Selatan yang menyatakan bahwa petani mahoni dan jabon melakukan kegiatan pemeliharaan berupa penyiapan lahan, pemupukan, penyulaman, dan pembersihan gulma, bahkan untuk tanaman mahoni diperlukan kegiatan pemangkasan (prunning). Pemangkasan untuk tanaman mahoni bertujuan untuk mencegah adanya serangan hama penggerek pucuk yang banyak menyerang tanaman mahoni. Menurut petani hutan di Kalimantan Selatan, kegiatan pemupukan sangat penting untuk tanaman khususnya tanaman mahoni. Pengalaman yang dimiliki petani berkorelasi positif (meskipun sangat lemah) dengan persepsi petani mengenai pengelolaan dan manfaat hutan rakyat pola agroforestri.

Petani di Wonogiri memiliki pengalaman bertani hutan rakyat pola agroforestri mulai dari 1-56 tahun. Semakin lama mereka mengelola hutannya maka akan semakin tinggi persepsinya sehingga makin positif memaknai pengelolaan dan manfaat hutan rakyat pola agroforestri. Berbekal pengalaman, petani mampu memperbandingkan teknik-teknik pengelolaan hutan rakyat yang benar sehingga hasil yang diperoleh dari hutan rakyat akan semakin besar. Pengelolaan hutan yang baik mampu memberikan manfaat (sosial, ekonomi, dan sosial) yang lebih baik kepada petani. Penelitian Jagoret et al., (2012) di Kamerun Tengah menunjukkan bahwa petani menerapkan inovasi agroforestri dalam kegiatan penghijauan. Hutan savana yang didominasi oleh alang-alang diubah menjadi kebun kakao yang dipadukan dengan tanaman kehutanan. Selain memberikan manfaat ekonomi, penanaman kakao dan tanaman kayu juga mampu memperbaiki tingkat kesuburan tanah.

Tingkat pendapatan berkorelasi positif (meskipun sangat lemah) terhadap persepsi petani mengenai pengelolaan hutan rakyat pola agroforestri. Semakin tinggi tingkat pendapatan petani maka beban terhadap hutan rakyat akan semakin kecil karena petani tidak menggantungkan hidupnya dari hutan rakyat semata. Hal ini mendorong petani untuk mengelola hutannya dengan baik, menggunakan teknik silvikultur yang baik mulai dari penyiapan lahan hingga pemanenan tanaman.

Tingkat pendapatan berkorelasi negatif (meskipun sangat lemah) terhadap persepsi petani mengenai manfaat hutan rakyat pola agroforestri. Tingginya pendapatan petani menyebabkan petani tidak mengandalkan hutannya sebagai sumber penghasilan utama sehingga keberadaan hutan rakyat belum dirasakan memberi manfaat terutama secara ekonomi kepada petani.

\section{Kesimpulan}

Persepsi petani mengenai pengelolaan hutan rakyat pola agroforestri tergolong tinggi, karena itu petani beranggapan bahwa pengelolaan hutan rakyat, mulai dari penyiapan lahan hingga pemasaran harus dilakukan dengan baik, namun petani masih beranggapan bahwa hutan rakyat memerlukan 
pemeliharaan yang intensif seperti tanaman semusim. Petani juga masih beranggapan bahwa dengan menanam tanaman kayu serapat mungkin maka keuntungannya akan semakin besar.

Persepsi petani mengenai manfaat hutan rakyat pola agroforestri tergolong tinggi. Petani merasa bahwa hutan rakyat telah memberikan banyak manfaat, terutama manfaat ekologi dan manfaat ekonomi.

Karakteristik petani yang berkorelasi nyata dengan persepsi petani mengenai pengelolaan hutan rakyat pola agroforestri adalah pendidikan formal, sedangkan pendidikan non formal berkorelasi sangat nyata. Karakteristik petani yang berkorelasi sangat nyata (negatif) dengan persepsi petani mengenai manfaat hutan rakyat pola agroforestri adalah jumlah tanggungan keluarga. Semakin besar jumlah tanggungan keluarga maka persepsi petani akan semakin rendah sehingga sambutan petani makin negatif terhadap manfaat hutan rakyat pola agroforestri. Hal ini dapat terjadi karena manfaat yang diperoleh petani dari hutan rakyat, terutama manfaat ekonomi belum dapat digunakan untuk memenuhi kebutuhan keluarga petani yang berjumlah besar.

\section{Daftar Pustaka}

Adhikari B, Williams F, Lovett JC. 2007. Local Benefits from Community Forests in the Middle Hills of Nepal. Forest Policy and Economics 9(2007): 464-478.

Anshori M. 2012. Pengelolaan Hutan Kemitraan untuk Menyejahterakan Rakyat, Kasus Kemitraan PHBM (Pengelolaan Hutan Bersama Masyarakat) di Perum Perhutani BKPH Parung Panjang, KPH Bogor [disertasi]. Bogor (ID): Sekolah Pascasarjana Institut Pertanian Bogor.

Asngari PS. 1984. Persepsi Direktur Penyuluhan Tingkat Karesidenan, dan Kepala Penyuluh Pertanian terhadap Peranan dan Fungsi Lembaga Penyuluhan Pertanian di Negara Bagian Texas, Amerika Serikat. Media Peternakan, 9(2):1-43

-------. 2008. Pemberdayaan Manusia Pembangunan yang Bermartabat. Medan (ID): Pustaka Bangsa Press.

Awang SA, Andayani W, Himmah B, Widayanti WT, Affianto A. 2002. Hutan Rakyat: Sosial Ekonomi dan Pemasaran. Yogyakarta(ID): BPFE Yogyakarta. Awang SA, Wiyono SB, Sandiyo S. 2007. Unit Manajemen Hutan Rakyat: Proses Konstruksi
Pengetahuan Lokal. Yogyakarta (ID): Banyumili

Badan Pusat Statistik Kabupaten Wonogiri. 2015. Wonogiri dalam Angka 2015. Wonogiri (ID): Badan Pusat Statistik Kabupaten Wonogiri.

[BRIK] Badan Revitalisasi Industri Kehutanan. 2010. Hutan Rakyat: Peran yang Makin Nyata. [internet]. [dapat diunduh di:http://www.brikonline.co.html].

Djamhuri TL. 2008. Community Participation in a Social

Forestry Program in Central Java, Indonesia: The Effect of Incentive Strucuture and Social Capital. Journal of Agroforest Syst 74 (2008):83-96.

Hardjanto. 2003. Keragaan dan Pengembangan Usaha Kayu Rakyat di Pulau Jawa. [disertasi]. Bogor (ID): Sekolah Pascasarjana IPB.

-------. 2015. Pengelolaan Hutan Rakyat: Tantangan Keilmuan dan Dunia Praktik ke Depan. Bogor (ID): IPB Press.

Hlaing EES, Inoue M. 2013. Factors affecting participation of user group members: comparative studies on two types of community forestry in the Dry Zone, Myanmar. Journal of Forest Research 18 (2013):60-72.

Jagoret P, Michel I, Dounias, Snoeck D, Ngnogue T, Malezieux E. 2012. Áfforestation of Savannah with Cocoa Agroforestri System: a Small Farmer Innovation in Central Cameroon. Agroforest Syst 86 (3):493-504.

Jarvis P. 2004. Adult Education and Lifelong Learning. Ed ke-3. London (UK): RoutledgeFalmer.

Kallio MH, Krsinawati H, Rohadi D, Kanninen M. 2011. Mahogany dan Kadam Planting Farmers in South Kalimantan: The Link Between Silvicultural activity and Stand Quality. Small-scale Forestry 10(1):115-132.

[Kemenhut]: Kementerian Kehutanan. 2010. Rencana Strategis 2010-2014. Jakarta (ID): Kementerian Kehutanan.

Moktan MR, Norbu L, Choden K. 2016. Can Community Forestry Contribute to Household Income and Sustainable Forestry Practices in Rural Area? A Case Study from Tshapey and Zariphensum in Bhutan. Forest Policy and Economics 62 (2016): 149-157.

Neuman WL. 2000. Social Research Method: Qualitative and Quantitative Approachs. $4^{\text {th }}$ ed. Allyn and Bacon. London (UK): Sage Publication Pratamaningtyas SNH. 2013. Kemampuan Anggota Kelompok dalam Pengelolaan Hutan Rakyat di Desa Tegal Waru, Kabupaten Bogor Provinsi Jawa 
Barat [tesis]. Bogor (ID): Sekolah Pascasarjana Institut Pertanian Bogor.

Rahut DB, Ali A, Behera B. 2015. Household Participation and Effects of Community Forest Management on Income and Poverty Levels: Empirical Evidence from Bhutan. Forest Policy and Economics 61(2015): 20-29.

Rohadi D. 2012. Analisis Persepsi dan Strategi Petani dalam Usaha Tanaman Kayu Rakyat (Studi Kasus Usaha Tanaman Kayu Rakyat di Kabupaten Gunung Kidul Daerah Istimewa Yogyakarta dan Kabupaten Tanah Laut, Provinsi Kalimantan Selatan) [tesis]. Bogor(ID): Sekolah Pascasarjana Institut Pertanian Bogor.

Rogers EM. 1995. Diffusion of Innovations. Ed Ke-4. New York (US): Free Press.

Scott JC. 1976. Moral Ekonomi Petani: Pengolahan dan Subsistensi di Asia Tenggara. Basari H, penerjemah; Rasuanto B, penyunting. Jakarta(ID): LP3ES. Terjemahan dari: The Moral Economy of The Peasant; Rebellion and Subsistence in South East Asia.

Simon H. 2010. Dinamika Hutan Rakyat di Indonesia. Yogyakarta (ID): Pustaka Pelajar.
Suprayitno AR, Sumardjo, Gani DS, Sugihen BG. 2012. Motivasi dan Partisipasi Petani dalam Pengelolaan Hutan Kemiri di Kabupaten Maros Provinsi Sulawesi Selatan (Motivation and Participation of Farmers in Managing Candlenut Forest in Maros District, South Sulawesi Province). Jurnal lmu Penyuluhan 8(2):184-199.

Suryaningsih WH, Purnaweni H, Izzati M. 2012. Persepsi dan Perilaku Masyarakat dalam Upaya Pelestarian Hutan Rakyat di Desa Karangrejo Kecamatan Loano Kabupaten Purworejo. Jurnal Ekosains 4(3):27-38.

Tologbonse EB, Jibrin MM, Auta SJ, Damisa MA. 2013. Factors influencing Women Participation in Women in Agricultural Development Project Nigeria. International Journal of Agricultural Economics and Extension 1(7):047-054.

Yadav BD, Bigsby H, McDonald I. 2015. How Can Poor and Disadvantaged Households Get An Opportunity to Become A Leader in Community Forestry in Nepal. Forest Policy and Economics 52(2015): 27-38. 